
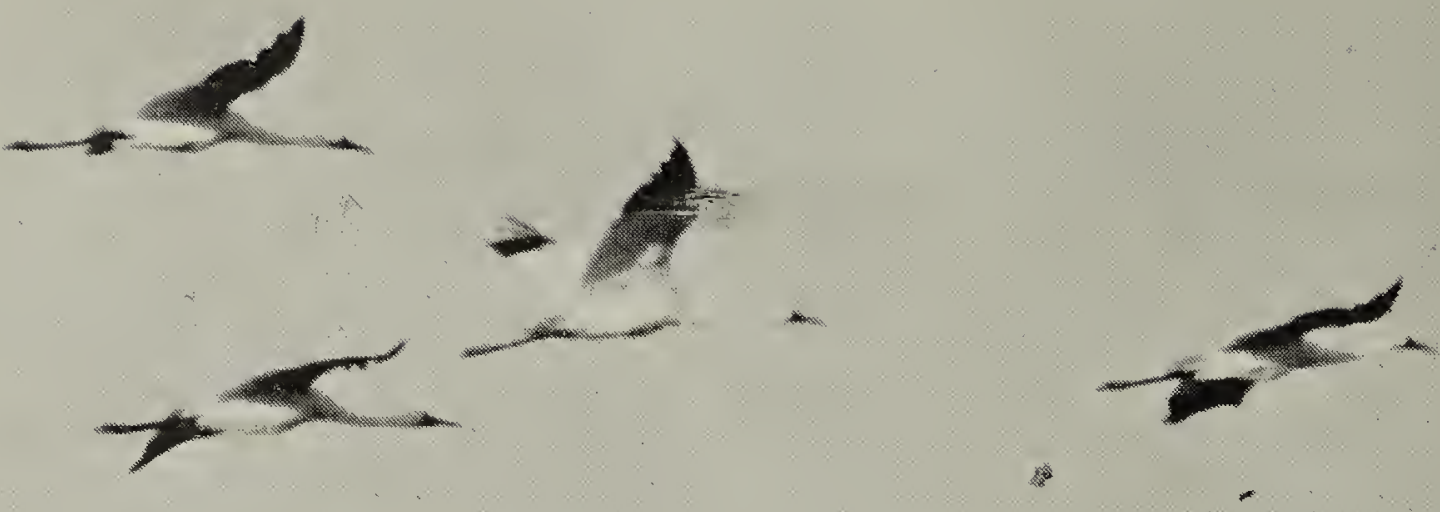

Whooping Cranes at Lucky Lake, Saskatchewan, October, 1973

Gary W. Seib

\title{
INDIAN BIRD IDENTIFICATION AND WHOOPING CRANES AT RED EARTH, SASKATCHEWAN
}

by DAVID MYER, SILAS HEAD, and DONALD McKAY

In the early winter of 1970-71, I began studies of the ethnography and history of the Red Earth Indian Reserves in east central Saskatchewan (see map). The scope of these studies included the gathering of information on the classification of birds, mammals and reptiles by the Red Earth Cree. During the summer of 1972, I continued my research at Red Earth and collected relatively complete information on the terms used by the Red Earth people for various species of birds. Also, some of the extensive Cree knowledge of avian behaviour was recorded.
To accomplish the identification of bird species in the Cree language, three men were questioned with the aid of illustrated texts in ornithology. The three men who made the species identifications were Silas Head, Donald McKay and George Head, aged 68,61 and 61 , respectively. The wives of these men also took an active part in the identification sessions, with the result that the final list of Cree terms for bird species was based on the efforts and knowledge of six persons. Donald McKay and his wife, Matilda, identified 104 species, George Head and his wife, Alice Amelia, knew 96 
species, and Silas Head and his wife, Mary Jane, 83 species. In some cases rare species were recognized but as these species had not been seen or spoken of for many years, their names were not recalled.

Altogether the three couples gave separate Cree names to 122 bird species that they recognized. For the most part, the identified species had been seen often and were regarded as common or regular inhabitants of the area. The total number of species thus identified compares favourably with the number of species found to nest in the general Nipawin area. ${ }^{2} 4$

The late Maurice Street found nests of 131 species within a 20 -mile radius of Nipawin, and recorded flightless young for 10 more species, bringing his breeding species to a remarkable total of $141 .^{2}$

It should also be stated that these ornithologists, as a result of decades of careful observation, have recorded 241 species of birds in the Nipawin area. Many of these are only occasional visitors to this part of the prairie provinces.

In the course of the collection of this information on birds, some data on Whooping Cranes also was obtained, mainly from Silas Head and Donald McKay. Since their accounts may be of interest, they are presented here.

\section{Whooping Cranes in the Red Earth Region (by Silas Head)}

A long time ago there were a few Whooping Cranes around here. One of he Indians from up north, whom I net, said there were a lot of Whooping Cranes up there. In Cree the Whooping Cranes are called "waapichichaak" (white cranes). The Sandhill Cranes, "ochichaak", are also ound here. They nest on the other side of Mountain Cabin. Their nests are very poor, made of little sticks. They ay three eggs in them.
My grandfather saw Whooping Cranes here a long time ago in the spring. They were walking in the water on the edge of the marsh between here and the south reserve, to this side of where Andrew's house is now (on the north side of the reserve). That was before the willows grew up there. My grandfather, Okimawipimotew, tried to kill them but he couldn't do it. He got very close but they flew before he shot. Miikwanaakeskam said he saw lots of white cranes out on the prairies before the white men came.

When I was a young man there were a few Whooping Cranes around Kennedy Creek to the north of here. We saw them just about every summer. One time, long ago, I was with a hunting party that was after moose on Kennedy Creek. One of the old men, Samuel Nawakayas, knew that we were there and he left Red Earth to come and join us. On his way he noticed some Whooping Cranes, two of them, and he went over to have a closer look. He tried to hunt the cranes but he was not able to shoot either of them. While he was there he found their nest. It was not a very good nest, just a few sticks on the ground in the swamp. He found three eggs in the nest and he took them to be eaten. When he found us at Kennedy Creek, he told us about the cranes and the eggs.

In the 1930's there was a big forest fire which burned throughout the whole territory to the north of Red Earth. It came from the west, from the farming settlement, and it burned across Kennedy Creek and as far east as the Sipanok Channel. After the fire we didn't see the Whooping Cranes anymore.

\section{Hunting Whooping Cranes in the old days (by Donald McKay)}

I have never seen a Whooping Crane myself. They are called "waapichichaak". My grandfather, Miik- 


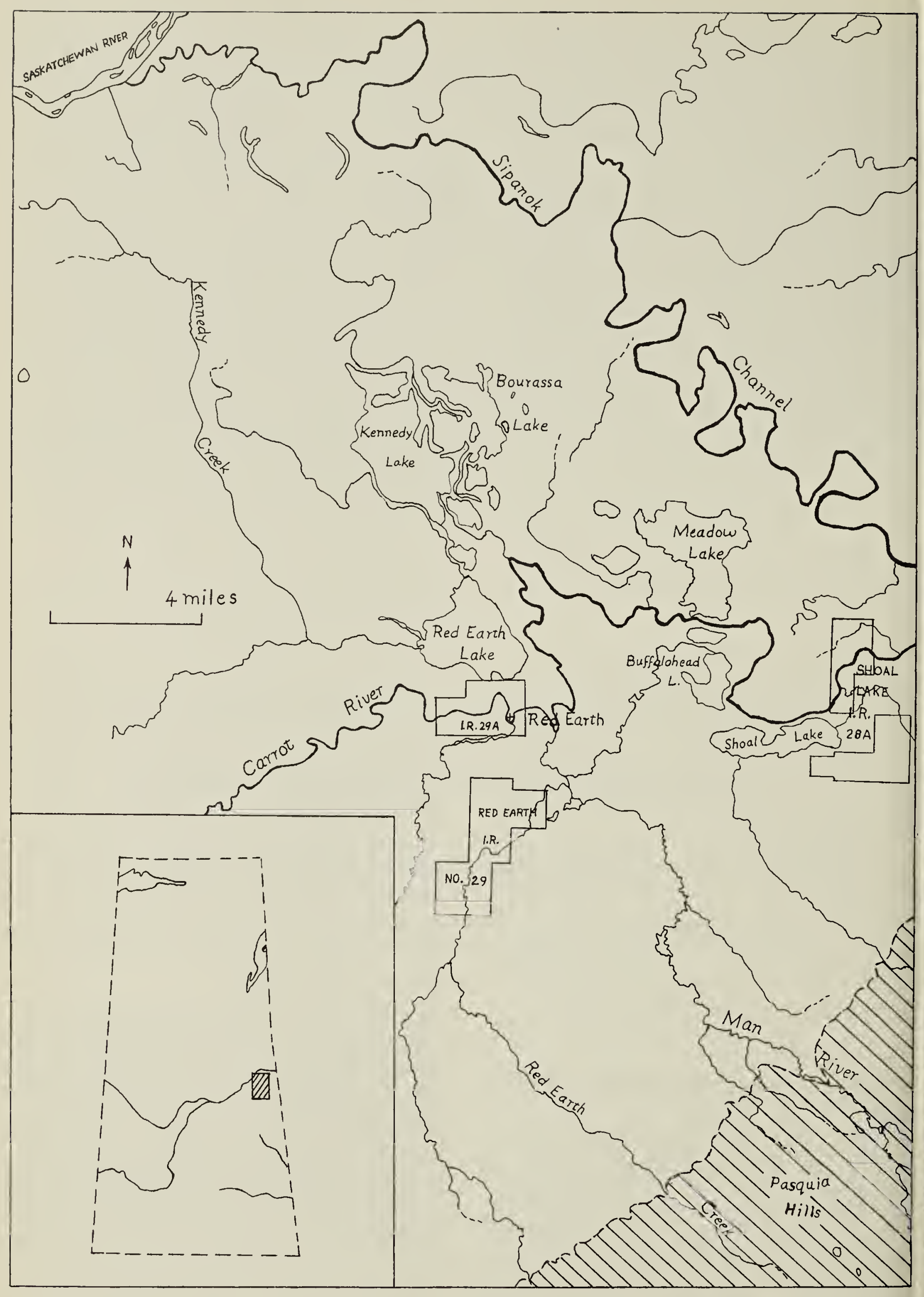

Map showing locations of Red Earth Indian Reserves, Saskatchewan. 
